\title{
STUDY OF ABNORMAL PALMER CREASES IN CHILDREN WITH AUTISM SPECTRUM DISORDER: A CASE-CONTROL STUDY IN NORTH INDIA
}

KEY WORDS:

\section{Avni Gupta}

\section{Aakanksha} Kharb*

\section{Dr. Sujata Sethi}

Junior Resident, Department of Psychiatry, Pt. B. D. Sharma Post Graduate Institute of Medical Sciences, Rohtak, Haryana.

Junior Resident, Department of Psychiatry, Pt. B. D. Sharma Post Graduate Institute of Medical Sciences, Rohtak, Haryana. *Corresponding Author

Senior Professor and unit head, Department of Psychiatry, Pt. B.D. Sharma Post Graduate Institute of Medical Sciences, Rohtak, Haryana.

INTRODUCTION: Autism Spectrum Disorder is a neurodevelopmental disorder characterized mainly by deficits in social and communication patterns. Aberrant gene environment interactions during fetal development leads to formation of minor physical anomalies such as abnormal palmar creases commonly seen in autism spectrum disorder.

AIM: To compare the prevalence of abnormal palmar creases in children with autism spectrum disorder and typically developing children.

METHODOLOGY: It was a case controlled cross sectional study conducted in departments of Psychiatry and Pediatrics of Pt. B.D. Sharma, PGIMS Rohtak. Fifty children of age 4-16 years with diagnosis of autism spectrum disorder (case group) and fifty typically developing children (control group) were recruited. A digital camera of 13 megapixels was used to click photographs of the palms of children. Palmar crease patterns of fifty children with diagnosis of autism spectrum disorder were compared with the control group.

RESULTS: The prevalence of abnormal palmar creases in case group was higher (47\%) than in control group (14\%). The prevalence of Simian crease in case group was double (22\%) as compared to one in control group i.e. $11 \%$. The prevalence of Sydney crease in case group was $21 \%$, while in control group it was only $3 \%$. The prevalence of Suwon crease in case group was $4 \%$, while it was not seen in control group.

CONCLUSION: Children with abnormal palmar creases help in early screening of neurodevelopmental disorders such as autism spectrum disorder helping in early management of these children leading to better outcomes and alleviation of parental stress and burden.

\section{INTRODUCTION}

Autism Spectrum Disorder (ASD) is a heterogeneous neurodevelopmental disorder characterized mainly by deficits in social and communication patterns.[1] DSM-5 groups the symptoms of ASD into two main categories: a) deficiencies in social interaction and communication, and b) patterns of repetitive and stereotypic movements.[2] This disorder is the second most common developmental disability, after intellectual disability. $[3,4]$ The etiology of autism spectrum disorder is a complex interaction of genetics with environmental insults, which may lead to an aberrant neurodevelopment.[5] This aberrant neurodevelopment may also be the cause of various minor physical anomalies commonly seen in children with ASD. As brain and the skin develop from the same neuroectodermal layer during the early fetal development, these minor physical anomalies can be the reflection of aberrant development of brain during embryogenesis.[6] There are various minor physical anomalies such as epicanthus, hypertelorism, adherent ear lobes, abnormal palmar creases and high steeped palate commonly seen in patients with autistic spectrum disorder.[7] Abnormal palmar creases are perhaps one of the first minor physical anomalies apparent in these patients. Palmar creases are formed well within the first trimester of pregnancy and there is no alteration thereafter.[8] Any insult at this stage of organogenesis would lead to altered brain development and abnormal palmar creases. So, presence of abnormal palmar crease may indicate the altered development of brain during early embryogenesis. The aim of the present study was to compare the prevalence of abnormal palmar creases in children with autism spectrum disorder and typically developing children.

\section{MATERIALS AND METHODS}

The index study was a case controlled cross sectional study conducted in the out-patient departments of Psychiatry and Pediatrics, of Pt. B.D. Sharma, PGIMS Rohtak. Ethical clearance was sought from Institutional Ethics Committee. Written informed consent from the parent and assent was taken from the children participating in the study.

Fifty children of 4-16 years of age of either gender, with diagnosis of autism spectrum disorder as per DSM- 5 criteria, and their parents attending the Child Guidance Clinic at department of Psychiatry, Pt. B.D. Sharma PGIMS, Rohtak constituted the study (case) group. Children with severe and profound mental retardation were excluded from this group. Fifty typically developing children, age and gender matched with the case group attending the Out- patient department of Pediatrics, Pt. B.D. Sharma PGIMS, Rohtak constituted the control group. The children were with major congenital malformations were excluded from this group.

After initial screening, final diagnosis of autism spectrum disorder was confirmed by the consultant psychiatrist. A specially designed proforma was used to gather sociodemographic and clinical details about the children and their parents. A digital camera of 13 megapixels (resolution of 3120 $\mathrm{X} 4160$ ) was used to click photographs of the palms of children in both groups, with white sheet of paper as a clear background. Camera lens was kept perpendicular to the line joining distal flexion crease of wrist and proximal flexion crease of the middle finger while clicking the photographs.[9] Photographs were evaluated in both the groups for palmar crease patterns. Children with diagnosis of autism were further assessed with Childhood Autism Rating Scale (CARS) and Indian Scale for Assessment of Autism (ISAA). [10,11]

The data thus collected was analyzed using descriptive statistics for discrete and continuous variables. Chi-square test was used for comparing the categorical variables and ttest was used for comparing the continuous variables.

\section{RESULTS}

There were total of one hundred children, fifty children in case and control group each. Table 1 shows various socio- 
demographic variables in both the groups. Majority of children in both groups were males and of age range of 4 to 7 years. Majority of the case group children had completed their primary education only as compared to the control group wherein children had moved to higher classes. In case group, 56\% children belonged to the urban background while majority of the children in control group belonged to the rural background.

TABLE 1 Various socio-demographic variables of case and control groups

\begin{tabular}{|c|c|c|c|c|}
\hline Variables & \begin{tabular}{|l|} 
Cases \\
$(n=50)$
\end{tabular} & \begin{tabular}{|l|}
$\begin{array}{l}\text { Controls } \\
(\mathrm{n}=50)\end{array}$ \\
\end{tabular} & $t / x 2$ & p -value \\
\hline \begin{tabular}{|l|} 
Age \\
$4-7$ years \\
$8-11$ years \\
$12-16$ years \\
\end{tabular} & $\begin{array}{l}20 \\
13 \\
17\end{array}$ & $\begin{array}{l}20 \\
13 \\
17\end{array}$ & 0.000 & $\begin{array}{l}1.000 \\
\text { Not } \\
\text { significant }\end{array}$ \\
\hline $\begin{array}{l}\text { Gender } \\
\text { Male } \\
\text { Female } \\
\end{array}$ & $\begin{array}{l}43 \\
07 \\
\end{array}$ & $\begin{array}{l}43 \\
07 \\
\end{array}$ & 0.000 & $\begin{array}{l}1.000 \\
\text { Not } \\
\text { significant } \\
\end{array}$ \\
\hline $\begin{array}{l}\text { Educational status } \\
\text { Primary (up to 5th } \\
\text { standard) } \\
\text { Secondary (6th- } \\
\text { 10th) }\end{array}$ & $\begin{array}{l}44 \\
06\end{array}$ & $\begin{array}{l}32 \\
18\end{array}$ & $\begin{array}{l}27.39 \\
3\end{array}$ & $\begin{array}{l}0.005 \\
\text { Significant }\end{array}$ \\
\hline \begin{tabular}{|l|} 
Birth order status \\
1 \\
2 \\
3 \\
$>3$ \\
\end{tabular} & $\begin{array}{l}28 \\
15 \\
05 \\
02\end{array}$ & $\begin{array}{l}21 \\
18 \\
08 \\
03 \\
\end{array}$ & 2.965 & $\begin{array}{l}0.539 \\
\text { Not } \\
\text { significant }\end{array}$ \\
\hline \begin{tabular}{|l|} 
Number of \\
children in family \\
1 \\
2 \\
3 \\
$>3$ \\
\end{tabular} & $\begin{array}{l}10 \\
26 \\
09 \\
05\end{array}$ & \begin{tabular}{|l|}
4 \\
23 \\
18 \\
05 \\
\end{tabular} & 7.755 & $\begin{array}{l}0.124 \\
\text { Not } \\
\text { significant }\end{array}$ \\
\hline $\begin{array}{l}\text { Adoption status } \\
\text { Yes } \\
\text { No } \\
\end{array}$ & $\begin{array}{l}0 \\
0 \\
\end{array}$ & $\begin{array}{l}0 \\
0 \\
\end{array}$ & - & - \\
\hline $\begin{array}{l}\text { Number of family } \\
\text { members } \\
3-5 \\
6-8 \\
9-11 \\
\end{array}$ & $\begin{array}{l}26 \\
16 \\
08 \\
\end{array}$ & $\begin{array}{l}29 \\
12 \\
09 \\
\end{array}$ & 8.241 & $\begin{array}{l}0.500 \\
\text { Not } \\
\text { Significant }\end{array}$ \\
\hline $\begin{array}{l}\text { Family structure } \\
\text { Nuclear } \\
\text { Extended } \\
\text { Joint } \\
\end{array}$ & $\begin{array}{l}32 \\
06 \\
12 \\
\end{array}$ & $\begin{array}{l}29 \\
12 \\
09 \\
\end{array}$ & 2.576 & $\begin{array}{l}0.276 \\
\text { Not } \\
\text { significant }\end{array}$ \\
\hline \begin{tabular}{|l|} 
Neighborhood \\
status \\
Rural \\
Urban \\
\end{tabular} & $\begin{array}{l}22 \\
28 \\
\end{array}$ & $\begin{array}{l}32 \\
18 \\
\end{array}$ & 4.652 & $\begin{array}{l}0.098 \\
\text { Not } \\
\text { significant }\end{array}$ \\
\hline
\end{tabular}

TABLE 2 Types of palmar crease both hands in case and control groups

\begin{tabular}{|c|c|c|c|c|c|}
\hline \multirow{2}{*}{$\begin{array}{l}\text { Palmar } \\
\text { crease } \\
\text { pattern } \\
\text { (both } \\
\text { hands) }\end{array}$} & \multicolumn{2}{|c|}{$\begin{array}{l}\text { Cases (N=100 } \\
\text { hands) }\end{array}$} & \multicolumn{2}{|c|}{$\begin{array}{l}\text { Controls } \\
\text { (N=100 hands) }\end{array}$} & \multirow[t]{2}{*}{\begin{tabular}{|l} 
P \\
Value
\end{tabular}} \\
\hline & Frequency & $\%$ & \begin{tabular}{|l|} 
Frequenc \\
$\mathbf{y}$
\end{tabular} & $\%$ & \\
\hline Normal & 53 & 53 & 86 & 86 & \multirow{5}{*}{$\begin{array}{l}<0.001 \\
\text { Significant }\end{array}$} \\
\hline Simian & 22 & 22 & 11 & 11 & \\
\hline Sydney & 21 & 21 & 3 & 3 & \\
\hline \multirow[t]{2}{*}{ Suwon } & 4 & 4 & 0 & 0 & \\
\hline & 100 & 100 & 100 & 100 & \\
\hline
\end{tabular}

TABLE 3 Types of palmar crease right and left hand in case and control groups

\begin{tabular}{|l|l|l|l|l|}
\hline $\begin{array}{l}\text { Palmar } \\
\text { crease }\end{array}$ & \multicolumn{3}{|l|}{ Right hand } & \multicolumn{2}{l|}{ Left hand } \\
\cline { 2 - 5 } & $\begin{array}{l}\text { Cases } \\
(\mathrm{n}=50)\end{array}$ & $\begin{array}{l}\text { Controls } \\
(\mathrm{n}=50)\end{array}$ & $\begin{array}{l}\text { Cases } \\
(\mathrm{n}=50)\end{array}$ & $\begin{array}{l}\text { Controls } \\
(\mathrm{n}=50)\end{array}$ \\
\hline
\end{tabular}

\begin{tabular}{|l|l|l|l|l|}
\hline & $\begin{array}{l}\text { Frequency } \\
(\mathbf{\%})\end{array}$ & $\begin{array}{l}\text { Frequency } \\
(\mathbf{\% )}\end{array}$ & $\begin{array}{l}\text { Frequency } \\
\mathbf{( \% )}\end{array}$ & $\begin{array}{l}\text { Frequen } \\
\text { cy (\%) }\end{array}$ \\
\hline Normal & $29(58)$ & $43(86)$ & $24(48)$ & $43(86)$ \\
\hline Simian & $12(24)$ & $5(10)$ & $10(20)$ & $6(12)$ \\
\hline Sydney & $9(18)$ & $2(4)$ & $12(24)$ & $1(2)$ \\
\hline Suwon & $0(0)$ & $0(0)$ & $4(8)$ & $0(0)$ \\
\hline P value & 0.007 Significant & $<0.001$ Significant \\
\hline
\end{tabular}

Table 4. Correlation of palmar crease patterns both hands of case group with gender

\begin{tabular}{|l|l|l|l|}
\hline $\begin{array}{l}\text { Palmar Crease } \\
\text { Pattern }\end{array}$ & $\begin{array}{l}\text { Males(86 } \\
\text { hands) }\end{array}$ & $\begin{array}{l}\text { Females(14 } \\
\text { hands) }\end{array}$ & P Value \\
\hline Normal & $44(51.1 \%)$ & $09(64.2 \%)$ & $\begin{array}{l}0.119 \\
\text { Simian }\end{array}$ \\
\cline { 1 - 3 } & $17(19.7 \%)$ & $05(35.7 \%)$ & significant \\
\hline Sydney & $21(24.4 \%)$ & $00(0 \%)$ & \\
\hline Suwon & $04(4.6 \%)$ & $00(0)$ & \\
\hline
\end{tabular}

Table 5. Severity of autism in case group by Childhood Autism Rating Scale-2nd edition (CARS-2)

\begin{tabular}{|l|l|l|}
\hline CARS-2 scores & \multicolumn{2}{|l|}{ Cases (n=50) } \\
\cline { 2 - 3 } & Frequency & $\%$ \\
\hline $30-36.5$ (mild to moderateautism) & 36 & 72 \\
\hline $37-60$ (severe autism) & 14 & 28 \\
\hline & 50 & 100 \\
\hline
\end{tabular}

Table 6 (a). Correlation of abnormal palmar creases (right hand) with scores on Childhood Autism Rating Scale-2nd edition (CARS-2)

\begin{tabular}{|l|l|l|l|l|}
\hline $\begin{array}{l}\text { Palmar crease } \\
\text { right hand }\end{array}$ & $\begin{array}{l}\text { Cases } \\
(\mathbf{n = 5 0 )})\end{array}$ & \multicolumn{2}{|l|}{ CARS-2 scores } & p \\
vean & Std. Deviation & \\
\hline Normal & 29 & 34.62 & 3.34 & 0.570 \\
\hline Simian & 12 & 33.92 & 2.59 & $\begin{array}{l}\text { Not } \\
\text { significant }\end{array}$ \\
\hline Sydney & 9 & 35.56 & 4.81 & \\
\hline & 50 & 34.62 & 3.46 & \\
\hline
\end{tabular}

Table 6 (b). Correlation of abnormal palmar creases (left hand) with scores on Childhood Autism Rating Scale- 2nd edition (CARS-2)

\begin{tabular}{|c|c|c|c|c|}
\hline \multirow{2}{*}{$\begin{array}{l}\text { Palmar } \\
\text { crease left } \\
\text { hand }\end{array}$} & \multirow{2}{*}{$\begin{array}{l}\text { Cases } \\
(n=50)\end{array}$} & \multicolumn{2}{|c|}{ CARS-2 scores } & \multirow[t]{2}{*}{ p value } \\
\hline & & Mean & Std. Deviation & \\
\hline Normal & 24 & 34.13 & 3.61 & \multirow{5}{*}{$\begin{array}{l}0.714 \\
\text { Not } \\
\text { significant }\end{array}$} \\
\hline Simian & 10 & 34.50 & 2.49 & \\
\hline Sydney & 12 & 35.50 & 3.76 & \\
\hline Suwon & 4 & \begin{tabular}{|l|}
35.25 \\
\end{tabular} & 4.35 & \\
\hline & \begin{tabular}{|l|}
50 \\
\end{tabular} & 34.62 & 3.46 & \\
\hline
\end{tabular}

Table 7. Severity of autism in case group by Indian Scale for Assessment of Autism (ISAA)

\begin{tabular}{|l|l|l|}
\hline \multirow{2}{*}{ ISAA Score } & \multicolumn{2}{|l|}{ Cases (n=50) } \\
\cline { 2 - 3 } & Frequency & $\%$ \\
\hline $70-106$ (mild) & 15 & 30 \\
\hline $107-153$ (moderate) & 27 & 54 \\
\hline$>153$ (severe) & 08 & 16 \\
\hline & 50 & 100 \\
\hline
\end{tabular}

Table 8 (a) Correlation of abnormal palmar creases (right hand) with scores on Indian Scale for Assessment of Autism (ISAA)

\begin{tabular}{|l|l|l|l|l|}
\hline $\begin{array}{l}\text { Palmar } \\
\text { creases right } \\
\text { hand }\end{array}$ & $\begin{array}{l}\text { Cases } \\
(\mathbf{n = 5 0 )}\end{array}$ & \multicolumn{2}{|l|}{ ISAA scores } & $\begin{array}{l}\text { p } \\
\text { value }\end{array}$ \\
\cline { 3 - 4 } & & Mean & Std. Deviation & \\
\hline Normal & 29 & 116.14 & 27.99 & 0.140 \\
\hline Simian & 12 & 104.75 & 24.07 & $\begin{array}{l}\text { Not } \\
\text { significant }\end{array}$ \\
\hline Sydney & 9 & 129.44 & 31.00 & \\
\hline & 50 & 115.80 & 28.26 & \\
\hline
\end{tabular}


Table 8 (b) Correlation of abnormal palmar creases (left hand) with scores on Indian Scale for Assessment of Autism (ISAA)

\begin{tabular}{|l|l|l|l|l|}
\hline $\begin{array}{l}\text { Palmar } \\
\text { Crease left } \\
\text { hand }\end{array}$ & $\begin{array}{l}\text { Cases } \\
(\mathbf{n = 5 0 )}\end{array}$ & \multicolumn{2}{|l|}{ ISAA scores } & \multirow{2}{*}{$\begin{array}{l}\text { p } \\
\text { value }\end{array}$} \\
\cline { 3 - 4 } & & Mean & Std. Deviation & \\
\hline Normal & 24 & 111.08 & 30.37 & $\begin{array}{l}0.285 \\
\text { Not } \\
\text { signific } \\
\text { ant }\end{array}$ \\
\hline Simian & 10 & 110.30 & 24.33 & \\
\hline Sydney & 12 & 129.42 & 22.70 & \\
\hline Suwon & 4 & 117.00 & 35.87 & \\
\hline & 50 & 115.80 & 28.26 & \\
\hline
\end{tabular}

Table 2 shows the prevalence of different types of palmar creases in both hands of case and control groups. Majority of children in control group had normal palmar creases. The prevalence of abnormal palmar creases was much higher in the case group than in control group and this difference was statistically significant $(\mathrm{p}<0.05)$

When two groups were compared for abnormal palmar creases in individual hands, the case group had higher prevalence for abnormal creases in both hands as compared to control group and this difference was statistically significant (Table 3). Suwon crease was seen only in left hand of the case group.

The severity of autism spectrum disorder in case group was assessed by Childhood Autism Rating Scale- 2nd edition (CARS). Out of 50 children with autism spectrum disorder, 36 had mild to moderate autism, and 14 had severe autism (Table 5). When patterns of palmar crease of both hands were compared with severity of autism spectrum disorder, the difference was not found to be statistically significant (Table 6).

On assessing severity of autism by Indian Scale for Assessment of Autism (ISAA), out of 50 children with autism spectrum disorder, 15 had mild autism, 27 had moderate and 8 had severe autism (Table 7). When patterns of palmar crease of both hands were compared with severity of autism spectrum disorder, the difference was not found to be statistically significant (Table 8).

However, no correlation of abnormal palmar creases was noticed with gender (Table 4) in both the groups or with severity of the disorder in the case group, as measured by CARS and ISAA (Tables 6-8).

\section{DISCUSSION}

The abnormal palmar crease patterns being developmental in nature and that too from neuroectoderm, may point towards the presence of neurodevelopmental disorder such as autism spectrum disorder. Our study was an attempt to estimate the prevalence of different types of abnormal palmar creases in children with autism spectrum disorder and to compare these with those seen in typically developing children. Majority of the children with autism spectrum disorder in our study belonged to the age group of 4-7 years with mean age of 6.5 years. This observation was similar to the findings of other studies. [12-16] In our study, $86 \%(n=43)$ children with autism spectrum disorder were males and this is similar to the findings of other studies[17-19] including Indian studies, which also mention the male preponderance in their study samples.[13,20] The finding that majority of children with autism spectrum disorder $(64 \%)$ in our study belonged to nuclear family (as compared to $58 \%$ in control group), is comparable to an Indian study in which $72.4 \%$ children with autism spectrum disorder belonged to nuclear family. [21] The overall prevalence of abnormal palmar creases in the case group was $47 \%$, as compared to $14 \%$ in control group. Among the abnormal palmar creases seen in the case group, prevalence of Simian crease (22\%) was slightly more than the Sydney crease $(21 \%)$, followed by Suwon crease $(4 \%)$. Not much of the research has been done on assessing the abnormal palmar creases lately, but one study on abnormal dermatoglyphics in adolescents with autism spectrum disorders by de Bruin et al reported a prevalence of $2.2 \%$ of Sydney crease. [22] We also tried to find correlation of palmar crease patterns in children with autism spectrum disorder to gender and severity of autism but could not find the difference to be statistically significant $(p>0.05)$. To our best of the knowledge no work is done in this area in recent times. We can infer at this stage from these findings that the presence of abnormal palmar creases may point towards the presence of some neurodevelopmental disorder such as autism spectrum disorder but it however, does not signify the severity of autism spectrum disorder.

\section{CONCLUSION}

This study is one of its kind in India that assesses the prevalence of different patterns of abnormal palmar creases in children with autism spectrum disorder. The comparison of abnormal palmar crease patterns in children with autism spectrum disorder with that in typically developing children provides further strength to the study results. Although it was a hospital-based study with a small sample size, so we cannot generalize the results into the community. The presence of abnormal palmar creases may prompt clinicians for early screening and early diagnosis and then timely institution of appropriate interventions leading to better outcomes in affected children and alleviation of parental stress and burden

\section{REFERENCES}

1. Grzadzinski, R., Huerta, M., \& Lord, C. (2013). DSM-5 and autism spectrum disorders (ASDs): an opportunity for identifying ASD subtypes. Molecular Autism,4(1), 1.https://doi.org/10.1186/2040-2392-4-12

2. Diagnostic and Statistical Manual of Mental Disorders: Diagnostic and Statistical Manual

of Mental Disorders, Fifth Edition. Arlington, VA: American Psychiatric Association, 2013.

3. William R. Lindsay, Derek Carson, Gregory O'Brien, Anthony J. Holland, John L. Taylor, Jessica Ruth Wheeler \& Lesley Steptoe (2014) A Comparison of Referrals With andWithout Autism Spectrum Disorder to Forensic Intellectual Disability Services, Psychiatry, Psychology and Law, 21:6, 947- 954, DOI: 10.1080/13218719.2014.918081

4. Yeargin-Allsopp, M., Rice, C., Karapurkar, T., Doernberg, N., Boyle, C., \& Murphy, C. (2003). Prevalence of autism in a US metropolitan area. JAMA, 289(1),49-55.https://doi.org/10.1001/jama.289.1.49

5. Freitag, C. (2007) The genetics of autistic disorders and its clinical relevance: a review of the literature. Mol Psychiatry 12,2-22.https://doi.org/10.1038/sj. mp.4001896

6. Cheung C, McAlonan GM, Fung YY, Fung G, Yu KK, Tai K-S, et al. (2011) MRI Study of Minor Physical Anomaly in Childhood Autism Implicates Aberrant Neurodevelopment in Infancy. PLoS ONE 6(6): e20246. https://doi.org/10. 1371 /journal.pone.0020246

7. McGrath,J.,El-Saadi, O., Grim, V., Cardy, S., Chapple, B., Chant, D., Lieberman, D., \& Mowry, B. (2002). Minor physical anomalies and quantitative measures of the head and face in patients with psychosis. Archives of general psychiatry, 59(5), 458-464.https://doi.org/10.1001/archpsyc.59.5.458

8. Steg, J. P., \& Rapoport, J. L. (1975). Minor physical anomalies in normal, neurotic, learning disabled, and severely disturbed children. Journal of autism and childhood schizophrenia, 5(4), 299-307.https://doi.org/10.1007/ BF01540677.

9. Tripi, G., Roux, S., Canziani, T., Brilhault, F. B., Barthélémy, C., \& Canziani, F. (2008). Minor physical anomalies in children with autism spectrum disorder. Early Human Development, 84(4), 217-223. https://doi.org/10.1016/j. earlhumdev.2007.04.005

10. Chlebowski, C., Green, J. A., Barton, M. L., \& Fein, D. (2010). Using the childhood autism rating scale to diagnose autism spectrum disorders. Journal of autism and developmental disorders, 40(7), 787-799. https://doi. org/10.1007/s10803-009-0926-x

11. Deshpande, S., Chakraborty, S.,Thomas, P., Bhatia, T., \& Nimgaonkar,V. (2015). Assessment of severity of autism using the Indian scale for assessment of autism. Indian Journal of Psychological Medicine, 37(2), 169. https://doi.org/ 10.4103/0253-7176.155616

12. Zuckerman, K., Lindly, O. J., \& Chavez, A. E. (2017). Timeliness of Autism Spectrum Disorder Diagnosis and Use of Services Among U.S. Elementary School-Aged Children. Psychiatric services (Washington, D.C.), 68(1), 33-40. https://doi.org/10.1176/appi.ps.201500549

13. Assis, Z. A., Bagepally, B. S., Saini, J., Srinath, S., Bharath, R. D., Naidu, P. R., \& Gupta, A. K. (2020). Childhood autism in India : A case - control study using tract - based spatial statistics analysis. https://doi.org/10.4103/00195545.166622

14. Constantino,J.N.,Zhang,Y.,Frazier,T.,Abbacchi, A. M., \& Law, P. (2010). Sibling recurrence and the genetic epidemiology of autism. The American journal of psychiatry, 167(11), 1349-1356. https://doi.org/10.1176/appi.ajp.2010. 09101470

15. Memari, A. H., Panahi, N., Ranjbar, E., Moshayedi, P., Shafiei, M., Kordi, R., \& Ziaee, V. (2015). Children with Autism Spectrum Disorder and Patterns of Participation in Daily Physical and Play Activities. Neurology Research International, 2015.https://doi.org/10.1155/2015/531906

16. Pisula, E., \& Porebowicz-Dörsmann, A. (2017). Family functioning, parenting 
stress andquality of life in mothers and fathers of Polish children with high functioning autism or Asperger syndrome. PloS one, 12(10), e0186536. https://doi.org/10.1371/journal.pone.0186536

17. Lord, C., Risi, S., DiLavore, P. S., Shulman, C., Thurm, A., \& Pickles, A. (2006). Autism from 2 to 9 years of age. Archives of general psychiatry,63(6), 694-701. https://doi.org/10.1001/archpsyc.63.6.694

18. Ugur, C., Tonyali, A., Goker, Z., \& Uneri, O. S. (2019). Birth order and reproductive stoppage in families of children with autism spectrum disorder. 0573.https://doi.org/10.1080/24750573.2018.1457489

19. Martin, L. A., \& Horriat, N. L. (2012). The Effects of Birth Order and Birth Interval on the Phenotypic Expression of Autism Spectrum Disorder. PLoS ONE, 7(11).https://doi.org/10.1371/journal.pone.0051049

20. Malhi, P., \& Singhi, P. (2014). Original Article A retrospective study of toddlers with autism spectrum disorder : Clinical and developmental profile. 17(1). https://doi.org/10.4103/0972-2327.128537

21. Mahapatra, Pranab \& Pati, Sanghamitra \& Sinha, Rajeshwari \& Chauhan, Abhimanyu \& Nanda, Rakesh \& Nallala, Srinivas. (2019). Parental careseeking pathway and challenges for autistic spectrum disorders children: $A$ mixed method study from Bhubaneswar, Odisha. Indian Journal of Psychiatry. 1.37-44.10.4103/psychiatry.IndianJPsychiatry_257_18.

22. Bruin, E I De Graham, J. H. Louwerse, A \& Huizink, A. C. (2014). Mild Dermatoglyphic Deviations in Adolescents with Autism Spectrum Disorders and Average Intellectual Abilities as Compared to Typically Developing Boys. 2014.https://doi.org/10.1155/2014/968134 